\title{
PENERAPAN AKUNTANSI AKRUAL PENDAPATAN PNBP PANAS BUMI
}

\section{APPLICATION OF ACCRUAL BASIS ACCOUNTING FOR NON-TAX STATE REVENUE FROM GEOTHERMAL BUSINESSES}

\author{
Siswanto \\ Polytechnic State of Finance STAN
}

\begin{abstract}
this study aims to look at the measurement of geothermal income on an accrual basis. Accrual basis is an accounting process of recording transactions carried out by an entity on the basis of the occurrence of the transaction in spite of the cash receiving. The business process of calculating geothermal revenues is carried out by a government entity called a work unit (satuan kerja). Working unit that carries out the task of recording and reporting geothermal revenue is called the non-tax state revenue work unit of the State General Treasurer (Bendahara Umum Negara/BUN) of geothermal management contained in the Directorate General of Budget. The study was conducted by studying the procedures and technical measures of accrual revenue from the revenues of geothermal businesses implemented by the geothermal management work unit. In addition, it also examined the applicable laws and regulations referred to by the work unit in carrying out the revenue recording process, then analyzed with the accrual-based accounting concept. The results of this study are that the laws and regulations governing the accounting for geothermal revenues already use the accrual basis, but in practice, they still need improvements at a practical level so that the concept of accrual-based accounting measurement can be applied perfectly.
\end{abstract}

Key words: geothermal, geothermal revenue, measuring

\begin{abstract}
ABSTRAK
penelitian ini bertujuan untuk melihat bagaimana proses pengukuran pendapatan panas bumi secara akrual. Basis akrual dalam akuntansi adalah sebuah proses pencatatan transaksi yang dilakukan oleh entitas dengan dasar keterjadian dari transaksi tersebut, bukan berdasarkan pada apakah uang kas sudah diterima atau belum. Proses bisnis perhitungan pendapatan panas bumi dilakukan oleh entitas pemerintah yang disebut satuan kerja (satker). Satker yang melakukan tugas mencatat dan melaporkan pendapatan panas bumi disebut satker penerimaan negara bukan pajak (PNBP) khusus Bendahara Umum Negara (BUN) pengelolaan panas bumi yang terdapat pada Direktorat Jenderal Anggaran. Penelitian dilakukan dengan cara mempelajari prosedur dan teknis mengukur pendapatan akrual penerimaan hasil usaha panas bumi yang dilaksanakan oleh satker pengelolaan panas bumi. Selain itu diteliti juga peraturan perundang-undangan yang berlaku yang diacu oleh satker pengelolaan panas bumi dalam melakukan proses pencatatan pendapatan tersebut, kemudian di analisis dengan konsep akuntansi berbasis akrual. Hasil penelitian ini adalah bahwa peraturan perundang-undangan yang mengatur mengenai akuntansi pendapatan panas bumi sudah menggunakan basis akrual, namun dalam pelaksanaannya masih dibutuhkannya penyempurnaan pada tataran praktis agar konsep pengukuran akuntansi berbasis akrual dapat diterapkan secara sempurna.
\end{abstract}

kata kunci: panas bumi, pendapatan panas bumi, pengukuran

Corresponding author: siswanto@pknstan.ac.id

Email : siswanto@pknstan.ac.id

DOI : https://doi.org/10.33369/j.akuntansi.9.3.197-212 


\section{PENDAHULUAN}

Panas bumi (geothermal) merupakan sumber energi alternatif yang sedang dilirik oleh pemerintah sebagai pengganti energi fosil yang semakin lama semakin sedikit cadangannya. Potensi sumber daya panas bumi Indonesia sangat besar, mengingat Indonesia adalah negara yang mempunyai banyak gunung berapi. Gunung berapi tersebut tersebar dari ujung Pulau Sumatera, Pulau Jawa, Pulau Bali, Pulau Lombok dan Pulau Sulawesi.

Menurut Undang-Undang (UU) Nomor 21 Tahun 2014 tentang Panas Bumi, panas bumi merupakan salah satu sumber daya alam non migas berupa sumber energi panas yang terkandung di dalam air panas, uap air, dan batuan bersama mineral ikutan dan gas lainnya yang secara genetik semuanya tidak dapat dipisahkan dalam suatu sistem panas bumi dan untuk pemanfaatannya diperlukan proses penambangan. Energi panas bumi terjadi karena adanya sumber panas yang sangat tinggi yang berada di bawah permukaan bumi. Panas yang sangat tinggi tersebut, menyebabkan semua benda atau batuan yang ada disekitarnya menjadi cair. Selanjutnya air yang terdapat didalam bumi tersebut apabila dapat keluar dari kerak bumi akan berubah menjadi uap. Uap panas bumi dapat dimanfaatkan sebagai salah satu energi yang dapat menghasilkan listrik. Sehimgga pada titik inilah energi panas bumi mulai memiliki nilai ekonomis.

Indonesia sebagai negara dengan penduduk yang sangat besar kurang lebih sebesar 280 juta jiwa membutuhkan sumber energi alternatif sebagai pengganti energi fosil untuk mengatasi krisis energi pada masa mendatang. Kondisi tektonik Indonesia yang merupakan Negara yang kaya akan sumber panasbumi dapat dimanfaatkan sebagai sumber energi alternatif terutama untuk pembangkit tenaga listrik dan sebagai sarana penunjang bagi pengembangan sektor industri, pertanian, perikanan dan potensi daerah yang lainnya. Pada masa mendatang potensi tersebut dapat dimanfaatkan sebagai sumber energi alternatif yang mampu memenuhi kebutuhan masyarakat (Setianingsih, 2011).

Energi listrik yang dihasilkan dari uap panas bumi tersebut dijadikan sebagai salah satu penerimaan negara dengan cara dijual kepada masyarakat. Pemanfaatan energi panas bumi tersebut, dilakukan pemerintah dengan membuat kontrak kerjasama dengan perusahaanperusahaan yang bergerak di bidang pengusahaan panas bumi. Perusahaan panas bumi yang sudah mendapatkan kontrak kerjasama kemudian melakukan kegiatan pengusahaan panas bumi yang antara lain eksplorasi, eksploitasi dan pemanfaatan. Kegiatan pemanfaatan panas bumi tersebut berdampak pada bertambahnya pendapatan negara dari sektor panas bumi yang disetor oleh pengusaha panas bumi.

Pendapatan negara dari sektor panas bumi merupakan kelompok Pendapatan Negara Bukan Pajak kelompok penerimaan Sumber Daya Alam (SDA) non migas. Berdasarkan data Kementerian Keuangan realisasi sementara penerimaan pemerintah dari SDA pada 2018 tumbuh 62,96\% menjadi Rp 161,1 triliun dari tahun sebelumnya. Nilai tersebut terdiri atas Rp 143,3 triliun $(80 \%)$ berasal dari sektor minyak dan gas dan sisanya non migas. Tahun ini, pemerintah menargetkan penerimaan SDA sebesar Rp190,75 triliun naik 12,37\% dari outlook 2018 atau 5,33\% dari realisasi sementara 2018. Penerimaan SDA tersebut terdiri atas penerimaan sektor migas Rp159,79 triliun (83\%) dan sisanya dari nonmigas. Harga minyak yang sempat naik hingga di atas US\$ 80/barel dan batu bara hingga US\$ 100/ton menjadi pemicu naiknya penerimaan SDA tahun lalu (Kementerian Keuangan RI, 2019).

Pendapatan Panas Bumi terdiri dari pendapatan setoran bagian pemerintah, iuran tetap, dan iuran produksi/royalti pertambangan panas bumi. Raihan Pendapatan Pertambangan Panas Bumi dari tahun 2015 s.d. tahun 2018 semakin meningkat sebagaimana grafik 1. Realisasi Pendapatan Pertambangan Panas Bumi pada tahun 2018 mencapai Rp2.252,65 
miliar naik sebesar 147 persen dibandingkan pendapatan tahun sebelumnya (Kementerian Keuangan RI, 2017, 2018, 2019).

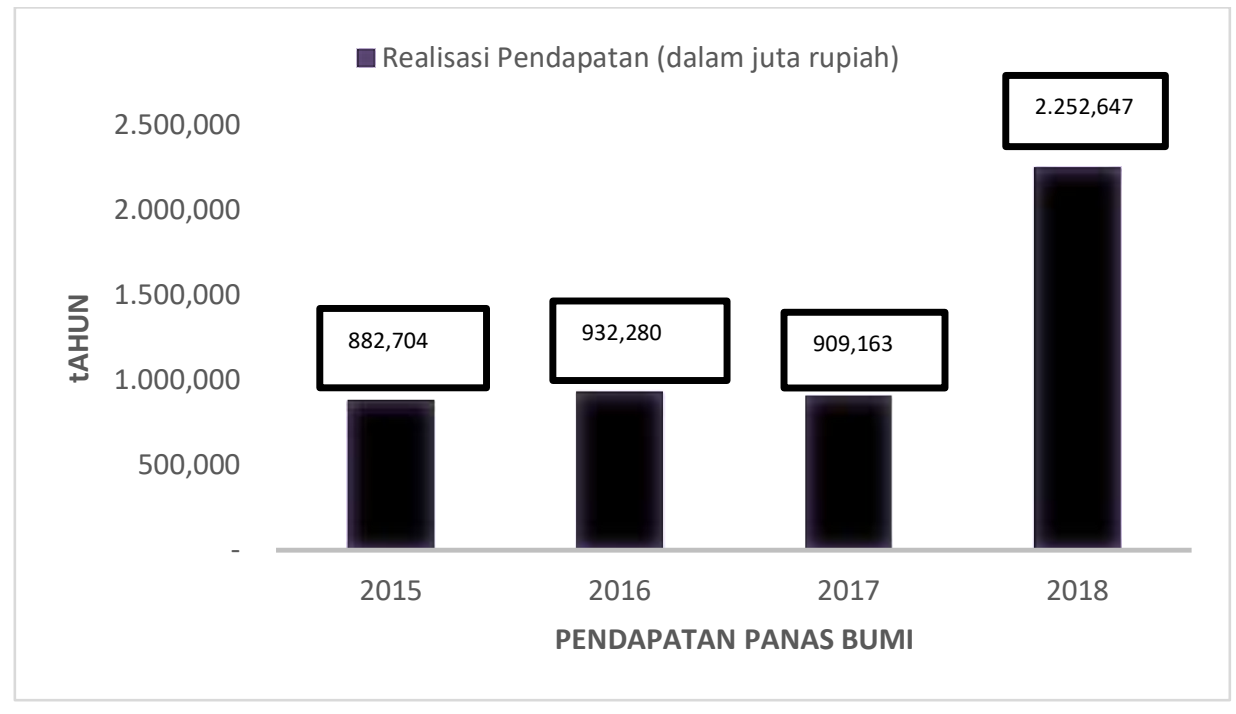

Grafik 1

Pendapatan Pertambangan Panas Bumi

Sumber: Laporan Keuangan Pemerintah Pusat (Audited)

Pendapatan yang diperoleh oleh pemerintah secara umum diakui dengan asas bruto, artinya seluruh yang diterima akan dicatat dan tidak boleh dikurangi dengan beban-beban yang terjadi dalam rangka memperoleh perndapatan tersebut. Namun demikian, asas bruto dapat dikecualikan penggunaanya apabila besaran pengurang terhadap pendapatan bruto (beban-beban) bersifat variabel terhadap pendapatan dimaksud dan tidak dapat diestimasi terlebih dahulu karena prosesnya belum selesai (asas neto).

Pendapatan Negara Bukan Pajak (PNBP) dari pengelolaan panas bumi yang dicatat dalam Laporan Realisasi Anggaran (LRA) dicatat dengan menggunakan asas neto. Asas ini diterapkan terhadap pendapatan panas bumi karena dalam unsur pemdapatan panas bumi yang diterima pemerintah masih terdapat komponen-komponen yang harus dikeluarkan sebagai beban yang menjadi kewajiban pemerintah terhadap berbagai pihak terkait. Wibowo (2016) mengemukakan bahwa asas neto masih diadopsi oleh Pemerintah dalam hal pengakuan Pendapatan-LRA. Hal ini dimaksudkan untuk tetap menjaga angka di dalam LRA tetap menyajikan uang negara yang memang sudah riil menjadi hak negara. Sementara itu, Terkait dengan implementasi basis akrual pada akuntansi Pemerintah Pusat, Yuwana, et al (2016) mengungkapkan bahwa pengungkapan Penerimaan Negara Bukan Pajak (PNBP) migas masih menggunakan asas neto yaitu berdasarkan pemindahbukuan dari rekening migas ke kas negara setelah bagian Pemerintah dipotong dengan faktor pengurang. Oleh karena itu perlu disesuaikan dengan basis akrual dengan penggunaan asas bruto agar pengelolaan migas dapat dievaluasi kinerjanya berdasarkan informasi akuntansi.

Penerimaan panas bumi yang diterima pemerintah ditetapkan sebesar 34\% (persen) dari Laba Bersih yang diperoleh pengusaha panas bumi. Dalam unsur penerimaan panas bumi, terdapat beberapa kewajiban yang harus ditunaikan pemerintah. Kewajiban-kewajiban tersebut antara lain reimbursement Pajak Pertambahan Nilai (PPN) bagi pengusaha panas bumi, Bonus Produksi yang sudah dibayarkan pengusaha panas bumi kepada daerah penghasil, serta Pajak Bumi dan Bangunan (PBB).

Banyaknya komponen yang melekat pada penerimaan panas bumi, menimbulkan banyak persepsi yaitu berapakah seharusnya PNBP panas bumi yang dicatat pada suatu 
periode tertentu?. Meskipun sudah ada peraturan yang menetapkan besarnya kewajiban pemerintah yang harus diperhitungkan untuk menghitung PNBP panas bumi, namun seringkali peraturan tersebut belum mempertimbangkan atau sulit diterapkan untuk memenuhi kaidah/prinsip akuntansi yang berlaku.

Prinsip atau kaidah akuntansi yang berlaku yang dimaksud adalah terkait basis pencatatan akrual dalam akuntansi pemerintahan. Basis pencatatan akuntansi akrual adalah prinsip mencatat sebuah transaksi berdasarkan keterjadiannya, bukan berdasarkan atas sudah diterima uang kasnya atau belum. Amanah untuk menerapkan basis akrual dalam penyusunan sudah ditetapkan oleh pemerintah melalui Undang-Undang Nomor (UU) 17 Tahun 2013 tentang Keuangan Negara pada Pasal 36 ayat (1) dan Undang-Undang Nomor 1 Tahun 2004 tentang Perbendaharaan Negara Pasal 70 ayat (1) (Republik Indonesia, 2003, 2004).

Penerapan basis akrual dalam akuntansi pemerintah pada perkembangannya mengalami banyak kendala. Kendala yang terjadi antara lain permasalahan begitu besarnya ruang lingkup entitas pemerintahan, baik pemerintahan pusat maupun pemerintahan daerah. Permasalahan lain adalah terkait kesiapan sumber daya manusia yang terbatas secara kuantitas dan kualitas untuk melakukan migrasi basis pencatatan akuntansi dari basis kas menuju akrual.

Peraturan Pemerintah sebagai pelaksanaan pencatatan basis akrual sudah ditetapkan sejak tahun 2005 dengan penerbitan Peraturan Pemerintah (PP) Nomor 24 tahun 2005 tentang Standar Akuntansi Pemerintahan yang kemudian diubah dengan Peraturan Pemerintah Nomor 71 tahun 2010. Sejak ditetapkannya, PP 71 tahun 2010 masih memberikan kesempatan kepada entitas pemerintahan untuk tidak menggunakan basis akrual sampai 5 tahun ke depan, sehingga implementasi dari penerapan basis akuntansi akrual pada entitas pemerintahan secara efektif baru dimulai pada tahun 2015 (Republik Indonesia, 2010b).

Penerapan basis akrual pada pemerintah pusat dan pemerintah daerah pada awalnya banyak menemui kendala, meskipun pada entitas pemerintahan pusat, permasalahan secara umum tidak begitu material dan signifikan. Permasalahan pada pemerintahan pusat lebih bersifat teknis dan kasuistis yang terjadi pada entitas satuan kerja khusus yang memang secara standar harus diperlakukan khusus mengingat jenis transaksinya yang juga sangat spesifik seperti transaksi-transaksi yang terjadi pada kegiatan usaha panas bumi ini.

Berdasarkan hal-hal tersebut di atas, penelitian ini bermaksud untuk menganalisis proses bisnis pengukuran pendapatan panas bumi secara akrual, bagaimanakah seharusnya pendapatan panas bumi dicatat/diukur berdasarkan kaidah/prinsip akuntansi yang berlaku? dan apakah peraturan-peraturan yang berlaku terkait proses pengukuran pendapatan panas bumi sudah mengatur sesuai dengan kaidah akuntansi?.

\section{KERANGKA TEORITIS}

\section{Akuntansi Pemerintah}

PP Nomor 71 tahun 2010 secara spesifik tidak mendefinikan apakah itu akuntansi pemerintah. Pasal 1 PP Nomor 71 tersebut mendefinisikan akuntansi secara umum yaitu sebagai sebuah proses identifikasi, pencatatan, dan pengikhtisaran transaksi keuangan yang kemudian dilaporkan dalam sebuah laporan keuangan serta diinterpretasikan atas hasilnya. Pemerintah yang dimaksud dalam PP 71 ini adalah meliputi pemerintah pusat dan pemerintah daerah. Sehingga apabila dikombinasikan, akuntansi pemerintah adalah sebuah proses mengidentifikasi, mencatat, dan mengikhtisarkan transaksi-transaksi keuangan yang terjadi pada pemerintah pusat dan pemerintah daerah, yang selanjutnya dibuatkan laporan keuangan dan diinterpretasikan hasilnya. 
Hamzah dan Kustiani (2014) menyatakan pemerintah dalam konteks akuntansi setidaknya merupakan unit yang memiliki karakteristik sebegai berikut:

1. Merupakan entitas yang tidak bertujuan memperoleh keuntungan. Pendapatan yang diperoleh secara umum bersifat "memaksa".

2. Pemerintah dimiliki secara kolektif oleh warganya. Hal ini berbeda dengan perusahaan, yang secara individu atau kelompok dimiliki oleh pihak-pihak yang memiliki modal pada perusahaan tersebut. Kepemilikan modal pada perusahaan dapat dinyatakan dalam bentuk saham atau yang sejenisnya dan dapat berganti-ganti. Sementara pemerintah yang secara kolektif dimiliki oleh warganya, tentu saja tidak dapat dengan mudah berganti-ganti secara kepemilikan.

3. Kontribusi sumber daya keuangan tidak dikaitkan langsung dengan pelayanan/produk yang diberikan oleh pemerintah. Hal ini bisa berarti bahwa pihak-pihak yang memberikan masukan sember daya kepada pemerintah, bisa jadi bukan pihak yang akan menerima manfaat atau layanan yang besar dari pemerintah. Sumber daya yang diperoleh pemerintah akan digunakan untuk seluruh warganya, baik yang besar memberikan kontribusi maupun yang memberikan kontribusi dalam jumlah kecil

4. Keputusan kebijakan dan keputusan operasional dibuat secara politis oleh lembaga perwakilan. Hal ini biasanya terjadi pada negara-negara yang menganut sistem demokrasi. Artinya bisa jadi, pihak yang membuat keputusan terkait anggaran dan keuangan bukan merupakan pihak yang kompeten memiliki pengetahuan tentang akuntansi.

5. Keputusan yang dibuat dilakukan secara terbuka sehingga akuntansi dan laporan-laporan lain yang terkait dengan pelaksanaan keputusan tersebut dapat diketahui oleh seluruh warga.

Suryanovi (2014) memberikan pengertian Akuntansi Keuangan Pemerintah Pusat sebagai suatu proses pengidentifikasian, pengukuran, pencatatan, pengklasifikasian dan pengikhtisaran transaksi dan kejadian keuangan Pemerintah Pusat, penginterpretasian atas hasilnya, serta penyajian Laporan Keuangan Pemerintah Pusat. Lebih jauh lagi dijabarkan pula bahwa penyelenggaraan akuntansi pemerintah pusat terkait dengan kegiatan pencatatan sampai dengan pelaporan atas transaksi sebagai berikut:

1. Saat anggaran disahkan dan dilakokasikan ke posnya masing-masing

2. Realisasi anggaran (realisasi pendapatan, belanja dan transfer serta penerimaan dan pengeluaran pembiayaan).

3. Perolehan dan pelepasan/pelunasan aset, kewajiban dan ekuitas.

4. Koreksi kesalahan

5. Penyesuaian dan penutup di akhir tahun, dan

6. Saat konsolidasi.

Sugijanto dalam Mulyana (2014) mendefinisikan akuntansi pemerintah adalah sebuah rangkaian proses meliputi aktivitas pencatatan, pengklasifikasian, pengikhtisaran, pelaporan transaksi-transaksi keuangan pemerintah sebagai suatu kesatuan dari unit-unitnya, serta penafsiran atas hasil aktivitas ini. Berdasarkan pengertian tersebut dapat disimpulkan beberapa kriteria yang dapat menjelaskan pengertian dan tujuan akuntansi pemerintahan, yaitu:

1. akuntansi merupakan aktivitas pencatatan, pengklasifikasian, pengikhtisaran dan pelaporan;

2. objek akuntansi pemerintahan adalah transaksi-transaksi keuangan pemerintahan sebagai implikasi dari pelaksanaan APBN/APBD;

3. tujuan akuntansi pemerintahan adalah laporan keuangan pemerintah yang merupakan laporan pertanggungjawaban dari pelaksanaan APBN/APBD.

Basis akrual 
Standar Akuntansi Pemerintah Basis akrual dalam PP Nomor 71 tahun 2010 mendefinisikan basis akrual adalah pencatatan kegiatan operasional pemerintahan serta posisi kekayaan dan kewajiban berdasarkan pengakuan munculnya hak dan kewajiban, bukan berdasarkan pada arus kas semata.

Basis akrual untuk laporan operasional (LO/laporan laba rugi dalam akuntansi komersial) berarti bahwa pendapatan diakui pada saat hak untuk memperoleh pendapatan telah terpenuhi walaupun kas belum diterima di Rekening Kas Umum Negara/Daerah atau oleh entitas pelaporan dan beban diakui pada saat kewajiban yang mengakibatkan penurunan nilai kekayaan bersih telah terpenuhi walaupun kas belum dikeluarkan dari Rekening Kas Umum Negara/Daerah atau entitas pelaporan. Pendapatan seperti bantuan pihak luar/asing dalam bentuk jasa disajikan pula pada LO.

Mulyana (2014) menjelaskan bahwa dalam pencatatan akuntansi dikenal terdapat 2 basis akuntansi yaitu basis kas dan basis akrual. Basis kas dalam akuntansi komersial telah diganti dengan basis akrual untuk penyusunan laporan keuangan. Sebelum penerbitan PP 71 Tahun 2010 yang menggantikan PP 24 Tahun 2005 tentang Standar Akuntansi Pemerintahan, Pemerintah Indonesia menggunakan basis akuntansi kas menuju akrual sebagai langkah strategis pemerintah untuk menyiapkan segala elemen yang diperlukan untuk penerapan basis akrual. Basis akuntansi akrual digunakan untuk pengakuan pendapatan-LO, beban, aset, kewajiban, dan ekuitas. Sementara itu, dalam hal pelaporan realisasi anggaran pemerintah yang disusun dengan perspektif basis kas maka pelaporan anggaran menggunakan basis kas.

\section{Pendapatan}

PP Nomor 71 tahun 2010 tentang Standar Akuntansi Pemerintahan mendefinisikan Pendapatan-LO sebagai hak pemerintah pusat/daerah yang diakui sebagai penambah ekuitas dalam periode tahun anggaran yang bersangkutan dan tidak perlu dibayar kembali. Dari definisi ini terlihat bahwa pengakuan pendapatan akrual tidak melihat pada aliran penerimaan kas pada Rekening Kas Umum Negara/Daerah melainkan lebih menekankan pada penambahan ekuitas dan tidak adanya ketentuan untuk dibayar kembali. Hal ini sekaligus untuk membedakan dengan penerimaan pembiayaan. Ha ini selaras dengan apa yang dinyatakan oleh Kiesso (2014) bahwa pendapatan merupakan peningkatan manfaat ekonomi selama periode akuntansi dalam bentuk arus masuk kas atau peningkatan aset, atau penurunan liabilitas yang mengakibatkan naiknya ekuitas yang tidak berasal dari transaksi yang terkait dengan kontribusi pemilik modal.

Selanjutnya, dalam PMK Nomor 224/PMK.05/2016 tentang Perubahan atas Peraturan Menteri Keuangan Nomor 219 /PMK.05/2013 tentang Kebijakan Akuntansi Pemerintah Pusat, pendapatan (Pendapatan-LO) didefinisikan sebagai hak pemerintah yang diakui sebagai penambah ekuitas dalam periode tahun anggaran yang bersangkutan dan tidak perlu dibayar kembali. Hak pemerintah tersebut dapat diakui sebagai Pendapatan-LO apabila telah timbul hak pemerintah untuk menagih atas suatu pendapatan atau telah erdapat suatu realisasi pendapatan yang ditandai dengan adanya aliran masuk sumber daya ekonomi.

Pendapatan-LO adalah pendapatan yang masuk dalam laporan keuangan pemerintah berupa Laporan Operasional. Diberikan tanda "LO" adalah untuk membedakan dengan pendapatan yang dilaporkan dalam Laporan Realisasi Anggaran. Pendapatan-LO merupakan pengakuan pendapatan berdasarkan basis pencatatan akrual, sementara itu pendapatan-LRA adalah pendapatan yang dicatat berdasarkan basis kas. Dalam konteks pendapatan yang diperoleh pemerintah, pendapatan dibagi menjadi 3 (tiga) jenis pendapatan, yaitu pendapatan perpajakan-LO, pendapatan PNBP-LO, dan pemdapatan hibah-LO. Pendapatan dari kegiatan usaha panas bumi merupakan bagian dari pendapatan PNBP-LO. 
Lampiran PMK Nomor 224/PMK.05/2016 tentang Perubahan atas Peraturan Menteri Keuangan Nomor 219 /PMK.05/2013 tentang Kebijakan Akuntansi Pemerintah Pusat diatur bahwa tujuan laporan keuangan adalah menyajikan informasi mengenai posisi keuangan, realisasi anggaran, saldo anggaran lebih, arus kas, hasil operasi, dan perubahan ekuitas suatu entitas pelaporan yang bermanfaat bagi para pengguna dalam membuat dan mengevaluasi keputusan mengenai alokasi sumber daya. Secara spesifik, tujuan pelaporan keuangan pemerintah adalah untuk menyajikan informasi yang berguna bagi pengambilan keputusan dan untuk menunjukkan akuntabilitas entitas pelaporan atas sumber daya yang dipercayakan kepadanya.

\section{Pendapatan Panas Bumi}

Berdasarkan Pasal 1 UU Nomor 17 Tahun 2003 tentang Keuangan Negara, Pendapatan negara adalah hak pemerintah pusat yang diakui sebagai penambah nilai kekayaan bersih. Sementara itu, rincian pendapatan negara terdiri dari penerimaan perpajakan, penerimaan negara bukan pajak dan penerimaan hibah.

Pendapatan panas bumi masuk dalam kelompok penerimaan negara bukan pajak (PNBP) yang apabila dirinci kembali masuk pada kelompok penerimaan pemanfaatan sumber daya alam. Sementara itu berdasarkan Pasal 1 PMK Nomor 221/PMK.02/2017, PNBP panas bumi adalah PNBP yang dikelola Bendahara Umum Negara yang berasal dari setoran bagian pemerintah setelah dikurangi dengan kewajiban perpajakan dan pungutan lainnya sesuai dengan peraturan perundang-undangan. Pendapatan panas bumi berasal dari setoran pengusaha panas bumi yang telah melakukan kegiatan ekplorasi dan eksploitasi panas bumi (usaha panas bumi) yang akan dijadikan sebagai sumber energi listrik. Pengusaha yang mempunyai kewajiban menyetorkan bagian pemerintah dari hasil usaha panas bumi adalah pengusaha yang dalam kegiatan operasinya sudah menghasilkan keuntungan.

Pengusaha panas bumi di Indonesia memperoleh pendapatan dari penjualan listrik kepada Perusahaan Listrik Negara (PLN). Listrik tersebut dihasilkan dari pembangkit listrik tenaga uap (PLTU) yang wajib dibangun oleh pengusaha panas bumi di lokasi pertambangan. Walaupun ada pendapatan lain dari kegiatan usaha panas bumi, contohnya penjualan uap panas bumi kepada pengusaha hotel di sekitar lokasi pertambangan, namun hasil penjualan tersebut tidak signifikan. Sehingga pendapatan utama pengusaha panas bumi adalah dari pembelian litrik oleh PLN.

Berdasarkan Keputusan Menteri Keuangan Nomor 766/KMK.04/1992 perhitungan setoran bagian pemerintah yang harus dibayarkan pengusaha panas bumi adalah sebesar $34 \%$ dari penerimaan bersih usaha (net operating income/NOI) dimana jumlah sebesar $34 \%$ x NOI tersebut juga diperlakukan sebagai pembayaran pajak penghasilan pengusaha. Sementara itu, kewajiban perpajakan lainnya seperti Pajak Pertambahan Nilai dan Pajak Bumi dan Bangunan akan dikembalikan kepada pengusaha oleh pemerintah. Sebagai informasi, sampai dengan saat ini, tata cara penghitungan dan penyetoran bagian pemerintah dari hasil usaha panas bumi untuk pembangkit listrik masih menggunakan dasar hukum KMK 766 tahun 1992, karena saat ini pengusaha-pengusaha yang sudah menyetorkan bagian pemerintah adalah pengusaha panas bumi dengan kontrak lama (rezim UU Nomor 27 tahun 2003). Sementara pengusaha panas bumi yang baru menjalankan kegiatan sejak rezim UU Nomor 21 tahun 2014 seluruhnya belum mendapatkan keuntungan karena memang biaya modal awal bisnis usaha panas bumi sangat besar. 


\section{METODE PENELITIAN}

Metode yang digunakan dalam penelitian ini adalah metode kualitatif dengan pendekatan studi kasus. Metode kualitatif merupakan metode yang digunakan untuk mengeksplorasi dan memahami makna yang berasal dari masalah sosial atau kemanusiaan melalui beberapa upaya penting, seperti mengajukan pertanyaan dan prosedur dan mengumpulkan data yang spesifik dari para partisipan (Creswell, 2015). Alasan pemilihan metode kualitatif dalam penelitian ini adalah karena laporan keuangan pemerintah merupakan suatu informasi yang harus disampaikan kepada masyarakat sebagai sebuah bentuk pertanggungjawaban dalam mengelola keuangan. Dengan menggunakan metode kualitatif ini diharapkan dapat diperoleh gambaran secara utuh tentang proses bisnis pengukuran pendapatan negara dari sektor panas bumi dan bagaimana prinsip akuntansi berbasis akrual mengatur pencatatan suatu transaksi, dengan demikian diharapkan nilai pendapatan panas bumi yang disajikan dalam laporan keuangan pemerintah semakin tinggi tingkat transparansi dan akuntabilitasnya.

Dalam penelitian kualitatif ini, penulis menggunakan strategi atau pendekatan studi kasus. Menurut Creswell (2015), studi kasus merupakan strategi penelitian untuk menyelidiki secara cermat suatu program, peristiwa, aktivitas, proses, atau sekelompok individu. Dalam hal ini, kasus yang diteliti dibatasi oleh waktu dan aktivitas dan peneliti mengumpulkan informasi secara lengkap melalui berbagai prosedur pengumpulan data berdasarkan waktu yang telah ditentukan (Stake dalam Creswell, 2015). Penggunaan strategi studi kasus dalam penelitian ini dimaksudkan untuk memperoleh informasi secara lengkap terkait proses bisnis penyusunan laporan keuangan pendapatan panas bumi.

Selanjutnya Yin (1989) dalam Wahyuningsih (2013) mengungkapkan bahwa terdapat tiga teknik analisis untuk studi kasus, yaitu (1) penjodohan pola, yaitu dengan menggunakan logika penjodohan pola. Logika seperti ini membandingkan pola yang didasarkan atas data empirik dengan pola yang diprediksikan (atau dengan beberapa prediksi alternatif). Jika kedua pola ini ada persamaan, hasilnya dapat menguatkan validitas internal studi kasus yang bersangkutan; (2) pembuatan eksplanasi, yang bertujuan untuk menganalisis data studi kasus dengan cara membuat suatu eksplanasi tentang kasus yang bersangkutan dan (3) analisis deret waktu, yang banyak dipergunakan untuk studi kasus yang menggunakan pendekatan eksperimen dan kuasi eksperimen.

Penelitian ini menggunakan teknik membuat eksplanasi, yaitu memahami proses pengakuan terciptanya pendapatan negara dari usaha panas bumi yang dilakukan oleh pengusaha. Kasus berupa terciptanya pendapatan panas bumi ini, kemudian dianalisis apakah proses pengakuan dan penghitungan serta pencatatan pendapatan panas bumi sudah sesuai dengan konsep akuntansi sebagaimana yang sudah ditetapkan dalam peraturan terkait akuntansi pemerintahan ataukah belum.

Secara rinci, metode penelitian yang dilakukan dalam penelitian ini adalah sebagai berikut:

1. Melakukan pengamatan dan observasi.

Tahap ini dilakukan oleh penulis pada saat masih bekerja pada Subdit Penerimaan Panas Bumi dan Hilir Migas, Direktorat Penerimaan Negara Bukan Pajak, Direktorat Jenderal Anggaran dalam kurun waktu tahun 2001 sampai dengan 2016. Penulis pernah secara langsung terlibat dalam proses penghitungan penerimaan negara dari usaha panas bumi di tahun 2001 sampai dengan 2006. Setelah itu, update informasi mengenai perkembangan terkait penerimaan negara dari usaha panas bumi dilakukan oleh penulis dengan berdiskusi dengan staf serta pejabat yang bidang tugasnya menangani secara langsung terkait penerimaan negara panas bumi. Selain itu, pengamatan juga dilakukan oleh 
penulis manakala dalam beberapa kesempatan mengikuti kegiatan rapat-rapat dan focus group discussion (FGD) yang melibatkan Direktorat Jenderal Minerba Pabum, Kementerian ESDM, Pertamina, pengusaha panas bumi, Direktorat Akuntansi dan Pelaporan Keuangan, Ditjen Perbendaharaan, serta unit-unit lainnya, serta kunjungan langsung (site visit) ke lokasi pertambangan seperti di Kabupaten Garut, Kabupaten Bandung, dan Kabupaten Tarutung.

2. Mempelajari literatur-literatur terkait. .

Tahap ini, penulis mempelajari literatur-literatur terkait dengan teori akuntansi, antara lain prinsip-prinsip akuntansi, teori basis pencatatan akuntansi pemerintah, teori pendapatan dan teori tujuan pembuatan laporan keuangan. Terkait dengan literatur dan peraturan-peraturan tentang pengusahaan panas bumi, mempelajari ketentuanketentuan/peraturan-peraturan yang mengatur pelaksanaan penyusunan laporan keuangan pemerintah khususnya pada satuan kerja pengelolaan pendapatan panas bumi.

3. Mempelajari implementasi penyusunan laporan keuangan terkait penerimaan panas bumi Pemerintah berbasis akrual pada satuan keja pengelolaan pendapatan panas bumi.

4. Melakukan analisis.

Analisis dilakukan terhadap penerapan penyusunan laporan keuangan pendapatan usaha panas bumi, kemudian juga melakukan analisis terhadap ketentuan-ketentuan yang mengatur pelaksanaan penyusunan laporan keuangan yang disusun satker pendapatan panas bumi.

5. Memberikan usulan yang dapat dilakukan oleh pengambil kebijakan, guna perbaikan dalam penerapan akuntansi pemerintah berbasis akrual di masa yang akan datang.

6. Menarik kesimpulan.

7. Memberikan masukan dan saran.

\section{PEMBAHASAN}

Indonesia sebagai negara yang memiliki gunung berapi yang cukup banyak, maka juga akan memiliki potensi energi yang dihasilkan dari panas bumi cukup besar. Petensi sumber daya alam yang dapat dihasilkan dari panas bumi adalah pemanfaatan uap panas bumi, yang dapat dikonversi menjadi energi listrik. Infrastruktur yang perlu dibangun dalam rangka mengubah energi panas bumi tersebut menjadi energi listrik adalah pembangkit listrik tenaga uap. Pemanfaatan energi panas bumi untuk diubah menjadi energi listrik di Indonesia masih sangat minim. PLN masih mengandalkan energi bahan bakar minyak (BBM) dan tenaga air dalam rangka mencapai target pemenuhan listrik di seluruh wilayah negara Indonesia. Namun demikian, produksi listrik dari energi panas bumi diprediksi akan senantiasa meningkat, seiring dengan makin menipisnya BBM dan makin gencarnya pemerintah mencari energi alternatif pengganti BBM, salah satunya adalah energi panas bumi yang diharapkan sebagai energi potensial pengganti BBM.

Seiring dengan meningkatnya pemanfaatan energi panas bumi, maka omset pengusaha panas bumi dari tahun ke tahun semakin meningkat. Indikasi meningkatnya pemanfaatan energi panas bumi adalah meningkatnya penerimaan negara dari kegiatan panas bumi dari tahun ke tahun. Kaitan antara pemanfaatan energi panas bumi dengan penerimaan negara dari kegiatan usaha panas bumi adalah bahwa panas bumi merupakan sumber daya alam yang sepenuhnya dimiliki oleh negara, dan ketika dimanfaatkan oleh pengusaha maka hasil dari pemanfaatan sumber daya alam tersebut sebagiannya harus disetorkan kepada negara dan negara akan mencatatnya sebagai pendapatan.

Hasil pengamatan dan wawancara yang dilakukan terkait mekanisme atau prosedur panas bumi menjadi penerimaan negara adalah sebagai berikut: 
Pengelolaan panas bumi dilakukan oleh badan usaha yang sudah memiliki izin usaha pertambangan (IUP). Kegiatan-kegiatan yang dapat dilakukan oleh badan usaha pemegang IUP adalah survei pendahuluan, eksplorasi, studi kelayakan, eksploitasi dan pemanfaatan. Badan usaha pemegang izin usaha mempunyai hak dan kewajiban antara lain melakukan kegiatan eksplorasi, studi kelayakan dan dan eksploitasi, menggunakan data dan informasi, serta memperoleh fasilitas perpajakan. Sementara itu, kewajibannya antara lain mematuhi peraturan perundang-undangan yang berlaku, mengelola lingkungan hidup, memprioritaskan pemanfaatan barang dan jasa yang berasal dari dalam negeri dan lain-lain.

UU No 27 tahun 2003 mengatur bahwa badan usaha pemegang IUP diwajibkan membayar pajak dan PNBP sesuai ketentuan perundang-undangan. Pajak yang dibayarkan terdiri dari pajak penghasilan, bea masuk dan pungutan impor, serta pajak daerah. Sementara PNBP yang mesti dibayarkan berupa iuran tetap dan iuran produksi serta pungutan negara lainnya. Meskipun dalam UU Nomor 27 tahun 2003 sudah diatur kewajiban-kewajiban keuangan badan usaha panas bumi, namun menurut nara sumber pada Seksi Penerimaan Usaha Panas Bumi total yang harus dibayarkan pengusaha panas bumi adalah sebesar 34\% dari laba bersih operasi (NOI), hal ini karena dalam aturan sebelumnya, yaitu Keputusan Presiden Nomor 49 tahun 1991 tentang Perlakuan Pajak Penghasilan, Pajak Pertambahan Nilai Dan Pungutan-Pungutan Lainnya Terhadap Pelaksanaan Kuasa Dan Ijin Pengusahaan Sumberdaya Panas Bumi Untuk Membangkitkan Energi/Listrik menetapkan bahwa kewajiban pengusaha panas bumi adalah sebesar 34\% dari NOI. Pasal 4 ayat (1) Keppres tersebut menegaskan bahwa kewajiban pengusaha panas bumi kepada negara hanya menyetorkan bagian pemerintah sebesar 34\% dari NOI dimana dalam jumlah 34\% tersebut sudah termasuk semua kewajiban pembayaran pajak-pajak dan pungutan-pungutan antara lain Pajak Penghasilan, Pajak Pertambahan Nilai atas Barang dan Jasa dan Pajak Penjualan Atas Barang Mewah, Pajak Bumi dan Bangunan, Bea masuk, Bea Meterai, kecuali pajak pribadi sesuai dengan peraturan perundang-undangan yang berlaku.

Batas maksimal 34\% setoran pengusaha panas bumi ini kemudian menjadi masalah pada tahun-tahun mendatang, disebabkan total $34 \%$ x NOI tersebut sudah merupakan seluruh kewajiban pengusaha kepada pemerintah. Apabila dihitung, maka hasilnya tidak akan mencukupi untuk menutupi seluruh kewajiban perpajakan pengusaha antara lain PPh, PPN, $\mathrm{PBB}$, bagi hasil dan bonus produksi. Sebagaimana dijelaskan di atas, kewajiban pengusaha panas bumi selain pajak juga berupa PNBP, dimana PNBP dari hasil usaha panas bumi juga tidak akan mendapatkan bagian dari 34\% x NOI kewajiban pengusaha. Setelah melakukan koordinasi secara maraton dengan instansi terkait antara lain dengan Ditjen Pajak, Ditjen Perbendaharaan, Ditjen Minerba Pabum, dan pengusaha panas bumi, maka diperoleh rumusan penghitungan PNBP dari kegiatan usaha panas bumi sebagaimana dijelaskan pada gambar 1 di bawah ini. 


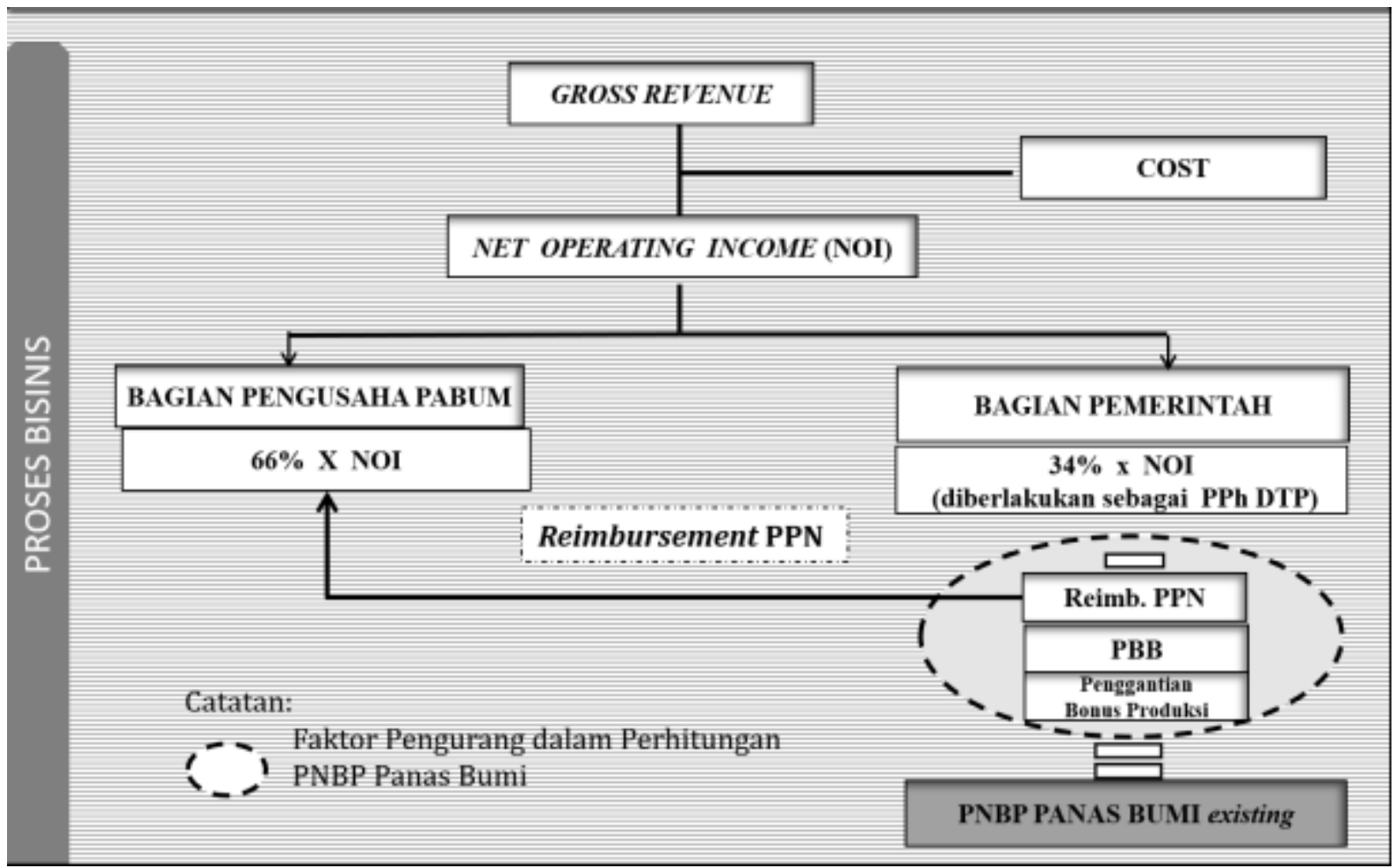

Gambar 1

Perhitungan Pendapatan Pertambangan Panas Bumi Sumber: Kementerian Keuangan

Berdasarkan gambar 1 tersebut, gross revenue pengusaha panas bumi akan dikurangkan terlebih dahulu dengan cost-nya, yaitu segala biaya untuk mendapatkan, menagih dan memelihara penghasilan. Berdasarkan Pasal 1 ayat (2) KMK Nomor 766/KMK.011/1992 sebagaimana diubah kedua kali dengan PMK Nomor 90 Tahun 2017, biaya-biaya tersebut adalah Pajak Pertambahan Nilai, Pajak Penjualan atas Barang Mewah, Pajak Bumi dan Bangunan, Bea Masuk, Bea Meterai dan Pungutan-pungutan lainnya. Secara lebih jelas aturan tersebut berbunyi sebagai berikut:

"Penerimaan Bersih Usaha (Net Operating Income) atau Penghasilan Kena Pajak (Taxable Income) adalah penghasilan sebagaimana dimaksud dalam Pasal 4 ayat (1) Undang-undang Pajak Penghasilan 1984 yang diterima atau diperoleh pengusaha dalam 1 (satu) tahun pajak setelah dikurangi dengan biaya untuk mendapatkan, menagih dan memelihara penghasilan sebagaimana dimaksud dalam Pasal 6 Undang undang Pajak Penghasilan 1984 tidak termasuk Pajak Pertambahan Nilai, Pajak Penjualan atas Barang Mewah, Pajak Bumi dan Bangunan, Bea Masuk, Bea Meterai dan Pungutan-pungutan lainnya."

Setelah didapatkan (Net Operating Income), maka pengusaha panas bumi akan menyetorkan sebesar 34\% kepada pemerintah melalui rekening penerimaan panas bumi Kementerian Keuangan pada Bank Indonesia. Dari setoran bagian pemerintah sebesar 34\% dari NOI tersebut akan dikeluarkan terlebih dahulu untuk pembayaran reimbursement PPN, PBB dan bonus produksi yang sudah diterima oleh daerah penghasil. Sisa dari setoran bagian pemerintah tersebut akan menjadi pendapatan pertambangan panas bumi yang merupakan bagian dari Penerimaan Negara Bukan Pajak (PNBP).

Setoran bagian pemerintah tersebut wajib disetor setiap triwulan yang besarnya adalah sebesar 34\% dari NOI triwulan yang bersangkutan. Setoran tersebut wajib dibayarkan oleh 
pengusaha paling lambat 30 (tiga puluh) bulan berikutnya. Tahapan selanjutnya adalah proses perhitungan pendapatan panas bumi. Perhitungan pendapatan pertambangan panas bumi dilakukan setiap triwulanan mengikuti setoran bagian pemerintahnya yang dibayarkan pengusaha panas bumi ke Kementerian Keuangan, hal ini sebagaimana disampaikan oleh nara sumber sebagai berikut:

"......, ngikutin setoran bagian pemerintahnya triwulanan"

Saat pengusaha panas bumi menyetorkan bagian pemerintah sebesar 34\% dari penerimaan bersih usaha ke rekening penerimaan panas bumi Kementerian Keuangan, Unit Akuntansi Kuasa Pengguna Anggaran (UAKPA) selaku pihak yang menyusun laporan keuangan tingkat satker pada saat itu belum melakukan pencatatan pendapatan pertambangan panas bumi. Sebagaimana gambar 1, UAKPA baru akan mencatat pendapatan pertambangan panas bumi manakala seluruh jumlah bagian pemerintah $(34 \% \mathrm{x}$ penerimaan bersih pengusaha) dikurangkan dengan hak-hak pengusaha, yaitu PPN, PBB dan dan pungutanpungutan lainnya.

\section{Pengukuran Pendapatan Panas Bumi Pada Penyusunan Laporan Keuangan}

Laporan keuangan yang dibuat oleh satker PNBP Panas bumi dilakukan pada periode semesteran dan tahunan. Permasalahan akan timbul manakala pendapatan panas bumi diukur dalam laporan keuangan pemerintah secara semesteran dan tahunan. Berikut ini adalah penjelasan mengenai proses mengukur PNBP panas bumi pada laporan semesteran dan laporan tahunan.

a. Laporan Keuangan Semesteran

Data pendapatan panas bumi yang akan dilaporkan dalam Laporan Operasional berasal dari setoran bagian pemerintah yang dilakukan oleh pengusaha panas bumi. Berdasarkan penjelasan dari nara sumber pada satker, saat penyusunan laporan keuangan semesteran, data setoran bagian pemerintah yang sudah dimiliki adalah baru periode triwulan I. Hal ini terjadi karena setoran bagian pemerintah dilakukan setiap triwulan paling lambat 30 hari setelah berakhirnya triwulan yang bersangkutan. Sehingga pada tanggal 30 Juni satker belum memiliki data setoran bagian pemerintah untuk periode triwulan II. Dengan demikian, dalam laporan keuangan semesteran nilai pendapatan panas bumi yang disajikan adalah berasal dari setoran bagian pemerintah periode bulan Januari - Maret. Nilai pendapatan panas bumi - LO murni berasal dari setoran bagian pemerintah, hal ini karena dalam pengakuan pendapatan panas bumi - LO yang dianut adalah azas bruto.

Berdasarkan penjelasan di atas, maka dalam laporan keuangan semesteran, pendapatan panas bumi - LO dianggap belum memenuhi kaidah akuntansi akrual. Nilai pendapatan panas bumi - LO tersebut belum menggambarkan hak pemerintah atas pendapatan yang seharusnya yaitu selama 6 bulan (Januari - Juni). Untuk memenuhi kaidah akuntansi akrual dalam penyusunan laporan keuangan, satker dapat membuat Berita Acara Rekonsiliasi (BAR) terkait data setoran bagian pemerintah. Dokumen BAR ini telah dinyatakan dalam PMK Nomor 221/PMK.02/2017 sebagai salah satu dokumen sumber yang dapat digunakan untuk mengakui pendapatan panas bumi. Namun demikian karena satker panas bumi tidak melakukan rekonsiliasi dengan pengusaha panas bumi, maka tidak ada dasar hukum untuk mencatat pendapatan panas bumi penuh sampai bulan Juni.

b. Laporan Keuangan Tahunan

Demikian pula hanya ketika satker menyusun laporan keuangan tahunan, data setoran bagian pemerintah baru diterima sampai dengan periode bulan September. Untuk periode triwulan IV belum diterima oleh satker. Namun demikian, berbeda dengan tahap penyusunan laporan keuangan semesteran, dalam proses penyusunan laporan keuangan 
tahunan, satker mengadakan rapat rekonsiliasi dengan pengusaha panas bumi dalam rangka mengestimasi setoran bagian pemerintah sampai akhir tahun. Hasil rapat ini akan dituangkan dalam BAR, dimana BAR akan menjadi acuan dalam menyusun laporan keuangan tahunan.

Berdasarkan penjelasan di atas, dalam penyusunan laporan keuangan tahunan dianggap sudah mencerminkan kaidah akuntansi akrual. Hal ini karena pendapatan panas bumi - LO yang dicatat sudah mencerminkan hak pemerintah atas pendapatan secara keseluruhan dalam satu tahun. Kondisi di atas adalah kondisi ideal yang terjadi dalam proses bisnis pendapatan panas bumi yang terjadi. Namun praktik di lapangan kondisi ideal tersebut tidak selalu terjadi, sehingga diperlukan penyesuaian-penyesuaian terhadap peristiwa yang terjadi agar proses pengukuran pendapatan panas bumi tetap pada kaidahnya, yaitu menyajikan laporan keuangan yang transparan dan akuntabel serta sesuai kaidah akuntansi berbasis akrual. Sebagai contoh, beberapa kejadian yang bisa terjadi yaitu antara satker dan pengusaha panas bumi tidak melakukan rekonsiliasi estimasi setoran bagian pemerintah, baik di pertengahan tahun maupun akhir tahun, sehingga tidak ada dokumen sumber yang dapat dijadikan acuan untuk mencatat pendapatan panas bumi secara penuh dalam periode semesteran maupun tahunan. Contoh lain yang dapat terjadi adalah terdapat sengketa di pengadilan antara pemerintah dengan pengusaha panas bumi, sehingga dapat terjadi kewajiban provisi, aset provisi serta kontijensi. Terkait hal ini, peraturan yang berlaku yaitu PMK Nomor 221/PMK.02/2017 belum mengatur secara rinci bagaimana perlakuan akuntansinya. Sehingga satker tidak dapat melakukan pencatatan atas peristiwa ini apabila diperlukan.

Dengan demikian meskipun PMK Nomor 221/PMK.02/2017 sebagai petunjuk teknis akuntansi panas bumi sudah mengacu pada akuntansi berbasis akrual, namun masih ada beberapa hal yang belum diatur dalam PMK tersebut. Sebagaimana contoh yang telah di jelaskan di atas.

Untuk tujuan pelaporan keuangan dalam menyajikan informasi mengenai posisi keuangan yang transparan dan akuntabel serta bermanfaat bagi para pengguna dalam membuat dan mengevaluasi keputusan mengenai alokasi sumber daya diusulkan agar dokumen sumber pengukuran jumlah pendapatan panas bumi dapat diperluas dengan dokumen-dokumen antara lain:

a. Pernyataan estimasi laba bersih yang diterbitkan badan usaha panas bumi.

b. Pernyataan estimasi setoran bagian pemerintah yang diterbitkan oleh pimpinan satker.

c. Pernyataan aset provisi, kewajiban provisi serta kontijensi dari ahli.

d. Kertas kerja perhitungan pendapatan panas bumi.

Dokumen tersebut harus dibunyikan/dinyatakan dalam suatu PMK tentang petunjuk teknis akuntansi panas bumi atau dapat juga dalam peraturan perundang-undangan di bawahnya. Dari pembahasan di atas, peraturan yang berlaku untuk acuan pengukuran pendapatan serta implementasi pengukuran pendapatan yang dilakukan oleh satker khusus panas bumi sudah mengacu akuntansi berbasis akrual, namun masih ada beberapa hal yang harus ditambahkan dalam peraturan tersebut agar laporan keuangan satker khusus pendapatan panas bumi akurat, transparan, dan akuntabel. Dengan demikian, laporan keuangan yang dibuat akan memuat angka pendapatan yang mencerminkan pendapatan secara murni untuk tahun yang berjalan.

\section{PENUTUP}

Pemerintah telah melakukan langkah-langkah yang diperlukan dengan menerbitkan peraturan perundang-undangan yang diperlukan sebagai pedoman bagi instansi pemerintah penyusun laporan keuangan pemerintah. Namun demikian, peraturan perundang-undangan 
yang ada dinilai belum dapat menyajikan secara akurat dan komprehensif terkait pendapatan pertambangan panas bumi yang mencerminkan pendapatan tahun berjalan secara penuh. Kondisi ini mengakibatkan proses pengukuran pendapatan panas bumi yang dilaksanakan oleh satker khusus panas bumi belum mencerminkan basis akuntansi secara akrual murni. Oleh karena itu, diperlukan beberapa penyempurnaan terhadap peraturan yang berlaku, sehingga laporan keuangan yang dihasilkan lebih akurat, transparan, komprehensif dan akuntabel. Sebagai contoh penyempurnaan yang dapat dilakukan adalah terkait perluasan aturan mengenai dokumen sumber yang dapat dijadikan dasar dalam pencatatan pendapatan panas bumi. Penyempurnaan atas peraturan dimaksud diharapkan dapat meningkatkan kualitas laporan keuangan pemerintah.

Hasil penelitian ini memberikan gambaran adanya implikasi kebijakan yang dapat ditempuh oleh Pemerintah untuk menyempurnakan prinsip, standar, dan metode dalam perlakuan akuntansi, khususnya terkait pendapatan pertambangan panas bumi. Beberapa kebijakan yang dapat dipertimbangkan untuk dituangkan dalam peraturan perundangundangan adalah:

a. Memperluas cakupan penetapan pengakuan pendapatan panas bumi antara lain dapat dengan menggunakan data RKAP atau meminta badan usaha menyampaikan estimasi setoran bagian pemerintah yang akan mereka setorkan diakhir tahun. Artinya adalah pengakuan pendapatan adalah pada saat pimpinan satker membuat pernyataan besarnya pendapatan panas bumi berdasarkan RKAP badan usaha panas bumi atau saat KPA menerbitkan Berita Acara Rekonsiliasi berdasarkan surat badan usaha panas bumi yang menyampaikan estimasi setoran bagian pemerintah.

b. Memperluas penetapan dokumen sumber pengukuran pendapatan panas bumi antara lain: 1) Pernyataan estimasi laba bersih yang diterbitkan badan usaha panas bumi; 2) Pernyataan estimasi setoran bagian pemerintah yang diterbitkan oleh pimpinan satker; 3) Pernyataan aset provisi, kewajiban provisi serta kontijensi dari ahli; 4) Kertas kerja perhitungan pendapatan panas bumi.

Dari sisi unsur-unsur laporan keuangan panas bumi, obyek penelitian ini terbatas pada unsur pendapatan panas bumi saja, sementara dalam pendapatan panas bumi yang berasal dari setoran bagian pemerintah masih terkandung unsur-unsur kewajiban pemerintah terhadap pengusaha panas bumi dan pihak ketiga. Dalam penyusunan Laporan Realisasi Anggaran, untuk menentukan Penerimaan Negara Bukan Pajak dari panas bumi, setoran bagian pemerintah tersebut harus dikurangkan terlebih dahulu dengan elemen kewajiban pemerintah dimaksud. Sementara dalam penyusunan Laporan Operasional, kewajiban pemerintah terhadap pengusaha panas bumi akan dilaporkan sebagai beban tersendiri. Sehingga dalam penelitian selanjutnya diharapkan dapat menganalisis bagaimana pengukuran beban-beban panas bumi terkait

Sementara itu dari sisi kajian akuntansi pemerintah secara umum, obyek penelitian ini terbatas pada satuan kerja khusus pendapatan pertambangan panas bumi. Sementara itu, satker yang mengelola pendapatan atau beban yang lainnya kemungkinan memiliki ragam permasalahan yang berbeda dengan satker pendapatan pertambangan panas bumi. Sehingga kemungkinan terdapat permasalahan-permasalahan lain yang terdapat pada satker pendapatan lainnya, namun belum tergambarkan dalam penelitian ini dan hasil penelitian ini tidak dapat diterapkan pada satker pendapatan tersebut. 


\section{DAFTAR PUSTAKA}

Creswell, J. P. (2015). Research Design. Pendekatan Kualitatif, Kuantitatif, dan Mixed. Edisi Ketiga (3rd ed.). Pustaka Pelajar, Yogyakarta.

Hamzah, A. P., \& Kustiani, A. (2014). DASAR-DASAR AKUNTANSI PEMERINTAHAN. Tangerang Selatan: STAN Press.

Kementerian Keuangan RI. (1992). KMK 766 Tahun 1992 tentang TATACARA PENGHITUNGAN, PENYETORAN DAN PELAPORAN BAGIAN PEMERINTAH, PAJAK PENGHASILAN, PAJAK PERTAMBAHAN NILAI DAN PUNGUTANPUNGUTAN LAINNYA ATAS HASIL PENGUSAHAAN SUMBERDAYA PANASBUMI UNTUK PEMBANGKITAN ENERGI/LISTRIK.

Kementerian Keuangan RI. PMK Nomor 224 Tahun 2016 tentang Kebijakan Akuntansi Pemerintah Pusat. , (2016).

Kementerian Keuangan RI. (2017a). Laporan Keuangan Pemerintah Pusat Tahun 2016 (Audited). https://doi.org/10.1017/CBO9781107415324.004

Kementerian Keuangan RI. PERATURAN MENTER! KEUANGAN REPUBLIK INDONESIA NOMOR 221 /PMK.O2/ 2017 TENTANG PETUNJUK TEKNIS AKUNJANSI PENERIMAAN NEGARA BUKAN PAJAK DARI KEGIATAN USAHA PANAS BUMI. , (2017).

Kementerian Keuangan RI. PERATURAN MENTER! KEUANGAN REPUBLIK INDONESIA NOMOR 90 /PMK.02/2017 TENTANG PERUBAHAN KEDUA ATAS KEPUTUSAN MENTER! KEUANGAN NOMOR 766/KMK.04/ 1992 TENTANG TATA CARA PENGHITUNGAN, PENYETORAN DAN PELAPORAN BAGIAN PEMERINTAH, PAJAK PENGHASILAN, PAJAK PERTAMB. , (2017).

Kementerian Keuangan RI. (2018). Laporan Keuangan Pemerintah Pusat Audited Tahun 2017.

Retrieved

from

http://www.bpk.go.id/assets/files/lkpp/2017/lkpp_2017_1527751554.pdf

Kementerian Keuangan RI. (2019). Laporan Keuangan Pemerintah Pusat Tahun 2018 (Audited). (15), 2943.

Mulyana, B. (2014). AKUNTANSI PEMERINTAH DAERAH BERBASIS AKRUAL. Tangerang Selatan: SEKOLAH TINGGI AKUNTANSI NEGARA.

Republik Indonesia. KEPUTUSAN PRESIDEN REPUBLIK INDONESIA NOMOR 49 TAHUN 1991 TENTANG PERLAKUAN PAJAK PENGHASILAN, PAJAK PERTAMBAHAN NILAI DAN PUNGUTAN-PUNGUTAN LAINNYA TERHADAP PELAKSANAAN KUASA DAN IJIN PENGUSAHAAN SUMBERDAYA PANAS BUMI UNTUK MEMBANGKITKAN ENERGI/LISTRIK. , (1992).

Republik Indonesia. Undang-Undang Nomor 27 Tahun 2003 tentang Panas Bumi. , (2003). Republik Indonesia. UNDANG-UNDANG REPUBLIK INDONESIA NOMOR 17 TAHUN 2003 TENTANG KEUANGAN NEGARA. , 18 Zitteliana § (2003).

Republik Indonesia. Undang-Undang Republik Indonesia Nomor 1 Tahun 2004 Tentang Perbendaharaan Negara. , (2004).

Republik Indonesia. Peraturan Pemerintah Nomor 71 Tahun 2010 (Standar Akuntansi Pemerintah Basis Akrual. , (2010).

Republik Indonesia. Peraturan Pemerintah Republik Indonesia Nomor 71 Tahun 2010. , Peraturan Pemerintah Republik Indonesia Nomor 71 Tahun $2010 \S$ (2010).

Republik Indonesia. (2014). Undang-Undang Nomor 21 Tahun 2014 tentang Panas Bumi.

Setianingsih, W. (2011). Potensi Lapangan Panasbumi Gedongsongo Sebagai Sumber Energi Alternatif Dan Penunjang Perekonomian Daerah. 8(1), 11-20. https://doi.org/10.15294/jg.v8i1.1652 
Suryanovi, S. (2014). BUKU SERI AKUNTANSI PEMERINTAH AKUNTANSI PEMERINTAH PUSAT ( BUKU 2 ). Tangerang Selatan: Sekolah Tinggi Akuntansi Negara.

Wahyuningsih, S. (2013). Metode Penelitian Studi Kasus: Konsep, Teori Pendekatan Psikologi Komunikasi, dan Contoh Penelitiannya. Bangkalan, Madura: UTM Press.

Wibowo, P. (2016). Menuju Kebijakan Akuntansi yang Paripurna: Studi Kasus Penerimaan Negara Bukan Pajak Sektor Hulu Migas. Revista Brasileira de Ergonomia, 9(2), 10. https://doi.org/10.5151/cidi2017-060

Yuwana, W. P., Djamhuri, A., Andayani, W., \& Ri, B. P. K. (2016). Analisis Atas Pengakuan Pendapatan Pajak Dan Migas Saat Permulaan Implementasi Basis Akrual Pada Akuntansi Pemerintah Pusat. 71-88. 